Sketsa Bisnis Volume (6) No (1) (2019) pp (1-12)

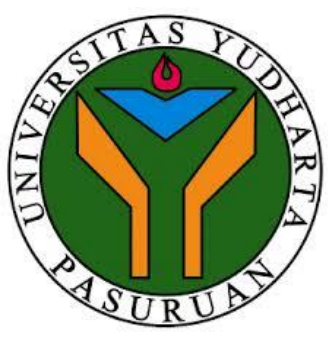
JURNAL SKETSA BISNIS

Naskah Diterima : 8 Juli 2019; Diterima Publikasi : 22 Agustus 2019

Journal Homepage

https://jurnal.yudharta.ac.id/v2/index.php/SKETSABISNIS

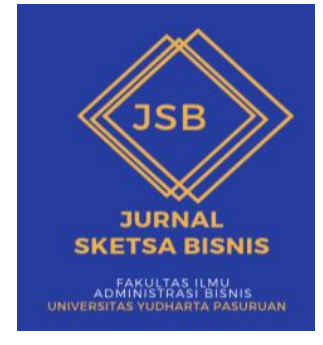

\title{
Pengaruh Tipe Industri, Profitabilitas dan Kinerja Lingkungan Terhadap Pengungkapan Islamic Social Reporting
}

(Studi Pada Perusahaan yang Terdaftar Di Jakarta Islamic Index Periode 2011-2015)

Nuraeni*, Anik Muilah

Prodi Administrasi Bisnis, Fakultas IImu Sosial Ilmu Politik,Universitas Yudharta Pasuruan

\section{Abstract}

This study aims to determine the effect of few variables, that is industiral type, profitability proxied by ROE and ROA, and environmental performance towards Islamic social reporting disclosure in companies listed in JII 2011-2015. The population in this study were all companies registered in JII 2011-2015, the sampling technique using purposive sampling, so that a total sample of 11 companies was obtained for five years, or equal to 55 annual reports. The analysis in this study is a descriptive statistical analysis by conducting a classic assumption test. The multiple linear regression analysis in this study uses SPSS 17 statistical analysis tools. The results of this study indicate that the Industry Type and Environmental Performance variables have no significant effect on Islamic Social Reporting Disclosure, while ROE has a significant negative effect and ROA has a significant positive effect on Islamic Social Reporting Disclosure.

Keywords: Industrial Type, ROE, ROA, Environmental Performance, Islamic Social Reporting Disclosure.

\begin{abstract}
Abstrak
Penelitian ini bertujuan untuk mengetahui pengaruh variabel tipe industri, profitabilitas yang diproksikan dengan ROE dan ROA, serta kinerja lingkungan terhadap pengungkapan islamic social reporting pada perusahaan yang terdaftar di Jll Periode 2011-2015. Populasi dalam penelitian ini adalah seluruh perusahaan yang terdaftar di JII periode 2011-2015, teknik pengambilan sampel dengan menggunakan purposive sampling, sehingga diperoleh total sampel sebanyak 11 perusahaan selama lima tahun, atau sama dengan 55 laporan tahunan. Analisis dalam penelitian ini merupakan analisis statistik deskriptif dengan melakukan uji asumsi klasik. Adapun analisis regresi linier berganda dalam penelitian ini menggunakan alat analisis statistik SPSS 17. Hasil penelitian ini menunjukkan bahwa variabel Tipe Industri dan Kinerja Lingkungan berpengaruh tidak signifikan terhadap Pengungkapan Islamic Social Reporting, sedangkan ROE berpengruh negatif signifikan dan ROA berpengaruh positif signifikan terhadap Pengungkapan Islamic Social Reporting.
\end{abstract}

Kata Kunci: Tipe Industri, ROE, ROA, Kinerja Lingkungan, Pengungkapan Islamic Social Reporting

*) Penulis Korespondensi: Nuraeni@gmail.com 


\section{Pendahuluan}

Perusahaan merupakan suatu bentuk lembaga yang berorientasi pada bisnis dan profit. Dalam dunia bisnis, perusahaan tidak hanya berfokus pada sebesar apa pendapatan yang akan didapat, namun juga harus memperhatikan tanggung jawabnya sebagai perusahaan yang berada diantara para pelaku bisnis, lingkungan dan masyarakat. Tanggung jawab sosial atau disebut juga dengan Corporate Social Responsibilty (CSR) secara umum dimaksudkan sebagai komitmen perusahaan agar tidak hanya berusaha mencari keuntungan dari kegiatan bisnisnya, namun juga menjaga hubungan yang baik dengan lingkungan sosial di sekitar tempat usahanya, dengan cara upaya-upaya yang menuju kepada peningkatan kehidupan komunitas setempat di semua aspeknya (Rama, 2014: 228).

Konsep penelitian dan praktik pertanggungjawaban perusahaan kini sudah mulai berkembang, terlihat dari banyaknya institusi yang mengarah pada sistem berbasis islami. Astuti (2013: 1-2) mengemukakan bahwa ekonomi islam sedang mengalami perkembangan dengan sangat pesat. Dalam Islam, konsep tersebut lebih menekankan dalam bentuk ketaqwaan umat manusia kepada Allah SWT dalam konteks perusahaan.

Peran perusahaan dalam berkontribusi memenuhi kebutuhan tentang pengungkapan tanggung jawab sosial perusahaan syariah yaitu dengan melakukan pengungkapan CSR berbasis islami yang disebut dengan Islamic Social Reporting atau ISR. ISR mengungkapkan hal-hal yang berkaitan dengan prinsip Islam misalnya transaksi yang sudah terbebas dari unsur riba, spekulasi dan gharar, juga mengungkapkan zakat, status kepatuhan syariah serta aspek-aspek sosial seperti shadaqoh, waqof, sampai dengan pengungkapkan peribadahan di lingkungan perusahaan (Merina, et al., 2016: 1-2).

Banyak faktor yang mempengaruhi pengungkapan ISR, salah satunya yaitu Tipe Industri, karena setiap perusahaan atau industri memiliki karakteristik yang berbeda dari berbagai aspek (Putri, et al., 2014: 7), faktor kedua yaitu profitabilitas yang diproksikan menggunakan ROE dan ROA, ketika perusahaan berada dalam profit yang tinggi, perusahaan akan terdorong melakukan pengungkapan informasi yang lebih luas dalam laporan tahunannya (Wulandari, 2016: 12), faktor lainnya yaitu kinerja lingkungan, Semakin banyak perusahaan memiliki prestasi dalam program lingkungan, maka pengungkapan ISR akan semakin luas (Kurniawati, 2016: 24).

Penelitian ini berfokus pada pasar modal syariah, Menurut (Nurhayati, et al., 2013:351-352), dalam pasar modal syariah, efek yang diperjual belikan harus merupakan efek syariah, yang meliputi saham syariah, obligasi syariah, Efek beragun Aset dan surat berharga lainnya. Penyertaan modal secara syariah tidak diwujudkan dalam bentuk saham syariah maupun non syariah, melainkan pada saham yang memenuhi kriteria syariah seperti Jakarta Islamic Index (JII), JII terdiri atas 30 saham syariah yang tercatat di Bursa efek Indonesia (BEI). Maka dari itu, perusahaan-perusahaan yang masuk dalam JII dapat mengungkapkan laporan tahunan yang bertujuan untuk memberi manfaat bagi pemangku kepentingan muslim.

Berdasarkan uraian latar belakang di atas, peneliti tertarik untuk memilih judul "Pengaruh tipe industri, ROE, ROA dan kinerja lingkungan terhadap pengungkapan Islamic Social Reporting pada perusahaan yang terdaftar di Jakarta Islamic Index (JII) Periode 2011-2015". 


\section{Kerangka Teori}

\subsection{Shari'ah Enterprise Theory}

Shari'ah Enterprise Theory merupakan konsep teoritis yang didasari dengan kesesuaian syari'ah dan terdapat nilai tauhidnya. Karena dengan konsep dan nilai ini kita dapat memperoleh legitimasi untuk memasukkan konsep kepemilikan dalam islam, konsep zakat, konsep keadilan ilahi, dan konsep pertanggung jawaban utamanya kepada Allah (Triyuwono, 2015: 356)

\subsection{Pengungkapan}

Istilah pengungkapan dalam akuntansi selalu berkaitan dengan penyajian dan pengungkapan corporate financial report. Dalam arti luas pengungkapan meliputi keluarnya setiap informasi tentang suatu perusahaan tertentu dalam pelaporan tahunan perusahaan, media massa, majalah dan sebagainya (Rama, 2014: 87).

\subsection{Tipe Industri}

Perusahaan atau industri adalah sebuah organisasi yang beroperasi dengan tujuan menghasilkan keuntungan, dengan cara menjual produk (barang dan atau jasa) kepada para pelanggannya (Hery, 2013: 1).

Variabel tipe industri diukur menggunakan variabel dummy, angka 1 untuk perusahaan manufaktur, dan angka 0 untuk perusahaan non-manufaktur (Othman et al., 2009: 9).

\subsection{Profitabilitas}

Profitabilitas merupakan cerminan level keuntungan perusahaan, yang dalam penelitian ini menggunakan 2 indikator utama yaitu:

\section{Return On Equit (ROE)}

$R O E$ merupakan suatu pengukuran dari penghasilan (income) yang tersedia bagi para pemilik perusahaan (baik pemegang saham biasa / commonstock maupun pemegang saham istimewa/ preferen) atas modal yang mereka investasikan di dalam perusahaan (Sartono, 2014: 124).ROE memusatkan pada pengembalian ekuitas pemegang saham (Brealey et al., 2008: 82), dalam penelitian ini ROE diukur dengan rumus sebagai berikut:

$$
\text { ROE }=\frac{\text { Laba Setelah Pajak }}{\text { Modal Sendiri }}
$$

2. Return On Asset (ROA)

Return on Asset berfungsi untuk melakukan pengukuran kemampuan perusahaan secara keseluruhan di dalam menghasilkan keuntungan dengan jumlah keseluruhan aktiva yang tersedia di dalam perusahaan. Semakin tinggi nilai dari rasio ini, semakin baik keadaan suatu perusahaan (Syamsudin, 2011: 63). ROA menunjukkan kemampuan perusahaan menghasilkan laba dari aktiva yang dipergunakan (Sartono, 2014: 123). dalam penelitian ini ROA diukur dengan rumus sebagai berikut:

$$
\text { ROA }=\frac{\text { Laba Setelah Pajak }}{\text { Total Aktiva }}
$$

\subsection{Kinerja Lingkungan}

Menurut (Kariza, 2015:3) Kinerja lingkungan dihasilkan oleh suatu perusahaan dalam periode tertentu dengan mengacu pada standar yang ditetapkan. Kinerja lingkungan hendaknya merupakan hasil yang dapat diukur dan menggambarkan kondisi empirik suatu perusahaan dari berbagai ukuran yang disepakati.

Pengukuran kinerja lingkungan hidup dalam penelitian ini dengan melihat prestasi perusahaan dalam mengikuti Program penilaian Kinerja Perusahaan dalam Pengelolaan Lingkungan Hidup (PROPER) yang diumumkan secara rutin oleh kementrian Lingkungan Hidup (KLH). Berikut Sistem peringkat kinerja PROPER mencakup pemeringkatan perusahaan dalam 5 warna, (Wulandari, 2015: 13) yakni: 
Tabel 1. Sistem peringkat PROPER

\begin{tabular}{|l|l|c|}
\hline Kategori & Predikat & Skor \\
\hline Emas & Sangat Baik & 5 \\
\hline Hijau & Baik & 4 \\
\hline Biru & Cukup & 3 \\
\hline Merah & Buruk & 2 \\
\hline Hitam & Sangat Buruk & 1 \\
\hline \multicolumn{2}{|l}{ Sumber: Wulandari, 2015 }
\end{tabular}

\subsection{Islamic Social Reporting (ISR)}

Islamic Social Reporting merupakan salah satu bentuk akuntabilitas dalam islam yaitu pelaporan tanggung jawab sosial perusahaan yang sesuai dengan normanorma islam (Anggraini et al., 2015:164). Islamic Social Reporting (ISR) Index memiliki dua tujuan utama, yaitu sebagai bentuk akuntanbilitas kepada Allah SWT dan masyarakat serta untuk meningkatkan transparansi kegiatan bisnis dengan memberikan informasi yang relevan dan sesuai dengan kebutuhan para pembuat keputusan muslim (Novrizal et al., 2016:179-180).

Indeks ISR dalam penelitian ini terdiri dari 43 item pengungkapan yang tersusun dalam enam tema sesuai dengan penelitian (Othman et al., 2010:137) yaitu pendanaan dan investasi, produk dan jasa, karyawan, sosial, lingkungan dan tata kelola perusahaan. Penilaian yang digunakan adalah sebagai berikut:

\begin{tabular}{|l|}
\hline $\begin{array}{l}\text { Nilai } 0 \text { untuk setiap item yang tidak } \\
\text { diungkapkan }\end{array}$ \\
\hline $\begin{array}{l}\text { Nilai } 1 \text { untuk setiap item yang } \\
\text { diungkapkan }\end{array}$ \\
\hline
\end{tabular}

Berikut rumus untuk menghitung besarnya disclosure level setelah scoring pada indeks ISR selesai dilakukan.

\section{Disclosure Level = \\ Jumlah skor disclosure yang dipenuhi Jumlah skor maksimum}

\section{Metode}

Penelitian ini menggunakan metode kuantitatif dengan jenis riset asosiatif, riset asosiatif merupakan riset yang bertujuan mengetahui hubungan atau pengaruh antara dua variabel atau lebih (Suliyanto, 2009:10). Hubungan tersebut bersifat Kausal yaitu hubungan yang bersifat sebab akibat, jadi disini ada variabel independen (variabel yang mempengaruhi) dan dependen (dipengaruhi) (Sugiyono, 2014: 37).

Populasi dalam penelitian ini adalah seluruh perusahaan yang terdaftar di Jakarta Islamic Index (JII) selama periode 2011-2015, yaitu sebanyak 30 perusahaan, sedangkan teknik sampel menggunakan purposive sampling yaitu pengambilan sampel yang hanya menurut kriteria, pemikiran atau pengetahuan pengambil sampel. Sampel yang terpilih secara otomatis dipengaruhi oleh pemahaman pengambil sampel terhadap populasi (Nursiyono, 2015: 25). Tahap pengambilan sampel adalah sebagai berikut:

Tabel 1. Tahapan Pengambilan Sampel

\begin{tabular}{|c|c|c|}
\hline No & Kriteria & $\begin{array}{c}\text { Jumlah } \\
\text { Perusahaan }\end{array}$ \\
\hline 1 & $\begin{array}{l}\text { Jumlah Perusahaan } \\
\text { yang terdaftar di JII } \\
\text { selama periode 2011- } \\
2015 \text { berturut-turut. }\end{array}$ & 19 \\
\hline 2 & $\begin{array}{lr}\text { Eliminasi } & \text { Perusahaan } \\
\text { yang tidak } & \text { mengikuti } \\
\text { PROPER } & \text { selama } \\
\text { periode } 2011-2015\end{array}$ & (8) \\
\hline 3 & $\begin{array}{l}\text { Perusahaan yang tidak } \\
\text { menerbitkan Annual } \\
\text { Report selama periode } \\
2011-2015\end{array}$ & (0) \\
\hline 4 & $\begin{array}{ll}\text { Jumlah perusahaan } \\
\text { sampel }\end{array}$ & 11 \\
\hline \multicolumn{2}{|c|}{$\begin{array}{l}\text { Total Sampel (11 perusahaan } \\
\text { x } 5 \text { tahun) }\end{array}$} & 55 \\
\hline
\end{tabular}

Data dalam penelitian ini merupakan data sekunder Berupa: daftar perusahaan yang masuk dalam saham Jakarta Islamic Index (JII) yang diperoleh dari www.sahamok.com, data peserta PROPER yang dipublikasikan selama tahun 2011- 
2015 yang didapat dari situs www.menlh.go.id, laporan tahunan (annual report) perusahaan terpilih yang diperoleh melalui situs www.idx.co.id.

Aanalisis yang digunakan dalam penelitian ini adalah analisis regresi berganda, dengan pendekatan analisis statistik deskriptif menurut (Sugiyono, 2013:206), statistik deskriptif adalah statistik yang digunakan untuk menganalisa data dengan cara mendeskripsikan atau menggambarkan data yang telah terkumpul. Pengukuran yang digunakan mencakup nilai rata-rata (mean), minimum, maksimum, standar deviasi, dan jumlah data penelitian yang akan disajikan dalam tabel numerik yang dihasilkan dari pengolahan data dengan menggunakan program SPSS versi 17. Berikut merupakan model konsep penelitian:

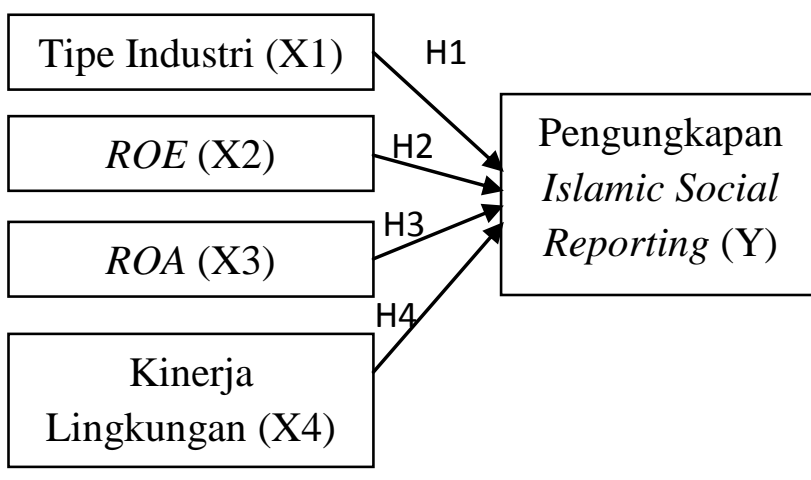

Sumber: Diolah Peneliti, 2017

\section{Gambar 1. Kerangka Konsep Penelitian}

Dari Konsep Penelitian Tersebut Maka di hasilkan hipotesis sebagai berikut:

H.1. Tipe Industri berpengaruh signifikan terhadap pengungkapan Islamic Sosial Reporting.

H.2. Return On Equity (ROE) berpengaruh signifikan terhadap pengungkapan Islamic Sosial Reporting

H.3. Return On Total Asset (ROA) berpengaruh signifikan terhadap pengungkapan Islamic Sosial reporting

H.4. Kinerja Lingkungan berpengaruh signifikan terhadap pengungkapan Islamic Sosial Reporting.
4. Hasil Penelitian Dan Pembahasan

4.1 Analisis Statistik Deskriptif

Tabel 2. Analisis Statistik Deskriptif

\begin{tabular}{|l|c|c|c|c|c|}
\hline & $\mathrm{N}$ & $\begin{array}{c}\text { Minimu } \\
\mathrm{m}\end{array}$ & $\begin{array}{c}\text { Maximu } \\
\mathrm{m}\end{array}$ & Mean & $\begin{array}{c}\text { Std. } \\
\text { Deviatio } \\
\mathrm{n}\end{array}$ \\
\hline ISR & 55 & .40 & .72 & .6123 & .06971 \\
$\mathrm{TI}$ & 55 & .00 & 1.00 & .5455 & .50252 \\
ROE & 55 & .02 & .30 & .1675 & .07422 \\
ROA & 55 & .02 & .25 & .1221 & .06664 \\
KL & 55 & 2.00 & 5.00 & 3.5273 & .79009 \\
Valid N & 55 & & & & \\
\hline
\end{tabular}

Sumber: Diolah Peneliti, 2017

Berdasarkan tabel di atas, hasil analisis deskriptif menunjukkan bahwa nilai Tipe Industri dengan nilai minimum yaitu 0 untuk perusahaan non manufaktur dan nilai maksimum yaitu 1 untuk perusahaan manufaktur, dapat diketahui jumlah perusahaan manufaktur yaitu sebanyak 6 perusahaan dan 5 perusahaan non manufaktur.

Variabel profitabilitas yang diwakili oleh $R O E$ memiliki nilai rasio tertinggi yaitu sebesar $30 \%$ di dapatkan oleh PT. Astra agro Lestari dan nilai rasio terendah sebesar 2\% didapatkan oleh PT. Vale Indonesia. Sedangkan $R O A$ memiliki nilai rasio tertinggi yaitu sebesar $25 \%$ di dapatkan oleh PT. Adaro Energy dan nilai rasio terendah sebesar $2 \%$ didapatkan oleh PT. Vale Indonesia.

Nilai kinerja lingkungan yaitu peringkat emas dengan skor 5 sebagai peringkat tertinggi dan peringkat terendah yaitu hitam dengan skor 1, disimpulkan bahwa ratarata perusahaan sudah menjalankan kinerja lingkungannya dengan baik karena hanya ada dua perusahaan yang mendapatkan peringkat merah yaitu Kalbe Farma Tbk dan Rumah sakit Lippo Karawaci kemudian tidak ada satupun perusahaan yang mendapatkan peringkat hitam. 
Nilai pengungkapan Islamic social Reporting (ISR) didapatkan bahwa nilai rata-rata sebesar $61 \%$ yang berarti ratarata banyak perusahaan yang mengungkapkan ISR lebih dari $50 \%$. nilai maximum sebesar $72 \%$ dihasilkan dari pengungkapan ISR yang dilakukan oleh PT. Indofood Sukses Makmur pada tahun 2013 dan PT. Indocement Tunggal Prakarsa pada tahun 2015 , sedangkan dari nilai terendah sebesar $40 \%$ dihasilkan oleh PT. Indocement Tunggal Prakarsa hanya pada tahun 2011, namun PT. Indocement Tunggal Prakarsa memperbaiki item pengungkapannya setiap tahun dibuktikan dengan pengungkapan ISR yang semakin tinggi setiap tahunnya.

\subsection{Hasil Uji Asumsi Klasik}

1. Uji Normalitas Normal P-P Plot of Regression Standardized
Residual

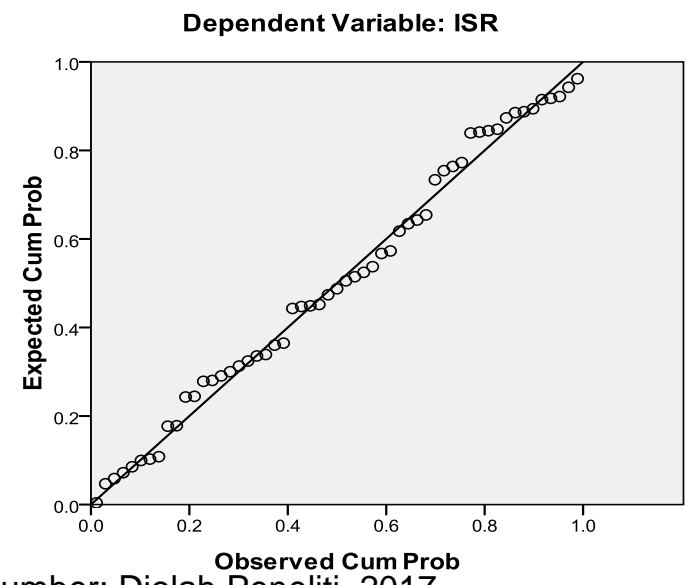

Sumber: Diolah Peneliti, 2017

Gambar 2. Uji Normalitas

Berdasarkan gambar di atas dapat disimpulkan bahwasannya ada pola yang jelas. Dimana titik-titik menyebar dan mengikuti garis diagonalnya. Maka dari itu dapat disimpulkan bahwasannya variabel-variabel dalam penelitian ini berdistribusi normal.

2. Uji Multikoliniearitas

Hasil pengujian multikolinieritas menunjukkan bahwa nilai VIF berada diantara 1-10 yang menunjukkan tidak terjadi multikolinieritas pada masingmasing variabel independen. Adapun hasil uji multikolinearitas ditunjukkan pada tabel 3:

Tabel 3. Uji Multikolinieritas

\begin{tabular}{|l|c|c|c|c|c|}
\hline \multirow{2}{*}{ Model } & \multicolumn{3}{c|}{ Correlations } & \multicolumn{2}{c|}{$\begin{array}{c}\text { Collinearity } \\
\text { Statistiks }\end{array}$} \\
\cline { 2 - 6 } & $\begin{array}{l}\text { Zero- } \\
\text { order }\end{array}$ & Partial & Part & Tolerance & VIF \\
\hline 1 (Constant) & & & & & \\
TI & .188 & .121 & .109 & .793 & 1.260 \\
ROE & .147 & -.286 & -.265 & .129 & 7.722 \\
ROA & .242 & .369 & .352 & .128 & 7.789 \\
KL & .216 & .258 & .237 & .750 & 1.334 \\
\hline
\end{tabular}

a. Dependent Variable: ISR

Sumber: Diolah Peneliti, 2016

Berdasarkan tabel tersebut, dapat dijelaskan bahwasannya dari hasil uji multikolinieritas menunjukkan nilai VIF berada diantara 1-10 yang menunjukkan tidak terjadi multikolinieritas pada masing-masing variabel independen.

3. Uji Autokorelasi

Tabel 4. Uji Autokorelasi

\begin{tabular}{|l|c|c|c|l|l|}
\hline Model & $\mathrm{R}$ & $\begin{array}{c}\mathrm{R} \\
\text { Square }\end{array}$ & $\begin{array}{c}\text { Adjusted R } \\
\text { Square }\end{array}$ & $\begin{array}{l}\text { Std. Error of } \\
\text { the Estimate }\end{array}$ & $\begin{array}{l}\text { Durbin- } \\
\text { Watson }\end{array}$ \\
\hline 1 & $.460^{\mathrm{a}}$ & .212 & .149 & .06431 & 1.616 \\
\hline
\end{tabular}

a. Predictors: (Constant), KL, ROE, TI, ROA

b. Dependent Variable: ISR

Sumber: Diolah Peneliti, 2017

Hasil analisa tabel menunjukkan nilai DW sebesar 1,616 yang berada diantara 1,55 - 2,46 (dilihat dari tabel ketentuan Uji Durbin Watson). Maka dapat disimpulkan bahwa tidak terdapat autokorelasi.

\section{Tabel 5. Ketentuan Uji Durbin Watson}

\begin{tabular}{|l|l|}
\hline \multicolumn{1}{|c|}{ Durbin Watson } & \multicolumn{1}{c|}{ Kesimpulan } \\
\hline Kurang dari 1,10 & Ada autokorelasi \\
$1,10-1,54$ & Tanpa Kesimpulan \\
$1,55-2,46$ & Tidak ada autokorelasi \\
$2,46-2,90$ & Tanpa Kesimpulan \\
Lebih dari 2,91 & Ada autokorelasi \\
\hline
\end{tabular}

Sumber: (Algifari, 2010:16) 
4. Uji Heteroskedastisitas Scatterplot

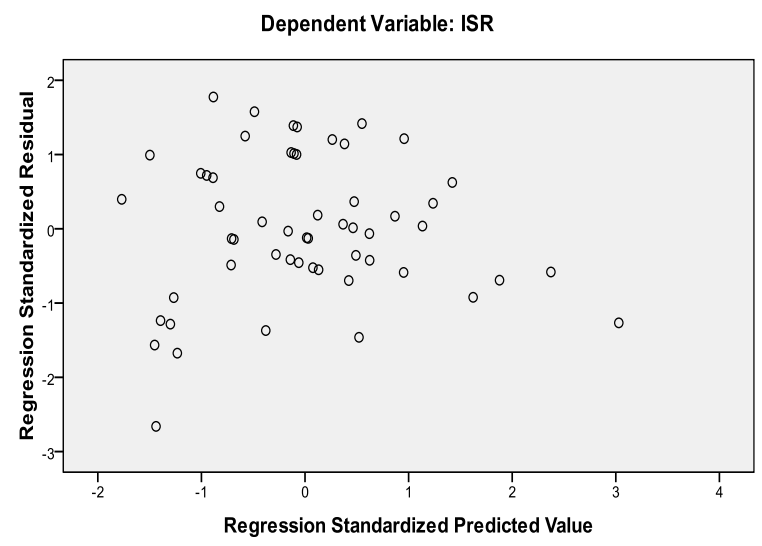

Sumber: Diolah Peneliti, 2017

\section{Gambar 3. Uji Heteroskedastisitas}

Berdasarkan grafik scatterplots tersebut, terlihat bahwa titik-titik data tidak mengumpul hanya di atas atau di bawah saja, hal ini dapat disimpulkan bahwa tidak terjadi heteroskedastisitas pada model regresi.

5. Uji Hipotesis

Tabel 6. Analisis Regresi Linier Berganda

\begin{tabular}{|c|c|c|c|c|c|}
\hline \multirow{2}{*}{ Model } & \multicolumn{2}{|c|}{$\begin{array}{c}\text { Unstandardize } \\
\mathrm{d}\end{array}$} & $\begin{array}{c}\text { Standa } \\
\text { rdized }\end{array}$ & \multicolumn{1}{|}{} \\
\cline { 2 - 4 } & $\mathrm{B}$ & $\begin{array}{c}\text { Std. } \\
\text { Error }\end{array}$ & Beta & $\mathrm{T}$ & Sig. \\
\hline 1 (Constant) & .508 & .046 & & 11.074 & .000 \\
$\mathrm{TI}$ & .017 & .020 & .122 & .864 & .391 \\
ROE & -.692 & .328 & -.736 & -2.110 & .040 \\
ROA & 1.029 & .366 & .983 & 2.807 & .007 \\
KL & .024 & .013 & .274 & 1.591 & .064 \\
\hline
\end{tabular}

a. Dependent Variable: ISR

Sumber: Diolah Peneliti, 2017

Berdasarkan hasil regresi yang ditunjukkan pada tabel 4.5 di atas, maka dapat diperoleh persamaan regresi sebagai berikut:

$\underline{\mathrm{ISR}}=0,508+0,122 \mathrm{TI}-0,736 \mathrm{ROE}+$ $\underline{0,983 \mathrm{ROA}+0,274 \mathrm{KL}+\mathrm{e}}$

a. $\alpha=0,508$

Koefisien konstanta bernilai positif sebesar 0,508 menunjukkaan bahwa pengungkapan Islamic Social Reporting (ISR) akan mengalami peningkatan jika dipengaruhi variabel Tipe Industri, $R O E, R O A$, dan Kinerja Lingkungan.

b. $\beta_{1}=0,122$

Koefisien Tipe Industri bernilai positif sebesar 0,122 Menunjukkan bahwa jika variabel Tipe Industri mengalami peningkatan maka Islamic Social Reporting (ISR) akan mengalami peningkatan sebesar 0,122 satuan dengan asumsi variabel-variabel bebas lainnya konstan.

c. $\beta_{2}=-0,736$

Koefisien $R O E$ bernilai negatif sebesar 0,736 menunjukkan bahwa jika variabel ROE mengalami peningkatan maka pengungkapan Islamic Social Reporting (ISR) akan mengalami penurunan sebesar 0,736 satuan dengan asumsi variabel-variabel bebas lainnya konstan.

d. $\quad \beta_{3}=0,983$

Koefisien $R O A$ bernilai positif sebesar 0,983 menunjukkan bahwa jika variabel $R O A$ mengalami peningkatan maka pengungkapan Islamic Social Reporting (ISR) akan mengalami peningkatan sebesar 0,983 satuan dengan asumsi variabel-variabel bebas lainnya konstan.

e. $\beta_{4}=0,274$

Koefisien Kinerja Lingkungan bernilai positif sebesar 0,274 menunjukkan bahwa jika variabel Kinerja Lingkungan mengalami peningkatan maka pengungkapan Islamic Social Reporting (ISR) akan mengalami peningkatan sebesar 0,274 satuan dengan asumsi variabel-variabel bebas lainnya konstan.

6. Uji Koefisien Determinasi $\left(R^{2}\right)$

Tabel 7. Koefisien Determinasi $\left(\mathbf{R}^{2}\right)$

\begin{tabular}{|c|c|c|c|c|}
\hline Model & $\mathrm{R}$ & $\begin{array}{c}\mathrm{R} \\
\text { Square }\end{array}$ & $\begin{array}{c}\text { Adjusted } \\
\text { R Square }\end{array}$ & $\begin{array}{c}\text { Std. Error of } \\
\text { the Estimate }\end{array}$ \\
\hline 1 & $.460^{\mathrm{a}}$ & .212 & .149 & .06431 \\
\hline
\end{tabular}


a. Predictors: (Constant), KL, ROE, TI, ROA

b. Dependent Variabel: ISR

Sumber: Diolah Peneliti, 2017

Tabel 7 menunjukkan bahwa nilai koefisien determinasi $\left(R^{2}\right)$ sebesar 0,212 atau $21,2 \%$ variabel Pengungkapan Islamic Social Reporting (ISR) dapat dijelaskan oleh keempat variabel independen yaitu Tipe Industri, ROE, ROA dan kinerja Lingkungan. Sedangkan sisanya $78,8 \%$ dipengaruhi oleh variabel lain diluar penelitian. Koefisien korelasi ( $R$ ) menunjukkan korelasi antara variabel independen terhadap Pengungkapan ISR adalah positif dengan nilai $46 \%$ menunjukkan pengaruh sedang. tabel pedoman interpretasi koefisien korelasi menurut Sugiyono (2010:231) adalah sebagai berikut:

Tabel 8. Pedoman Interpretasi Koefisien Korelasi

\begin{tabular}{|c|c|}
\hline Interval Koefisien & Tingkat Hubungan \\
\hline $0,00-0,199$ & Sangat Redah \\
\hline $0,20-0,399$ & Rendah \\
\hline $0,40-0,599$ & Sedang \\
\hline $0,60-0,799$ & Kuat \\
\hline $0,80-1,00$ & Sangat Kuat \\
\hline
\end{tabular}

Sumber: Sugiyono (2010:231)

7. Uji Parsial (Uji t)

Tabel 10. Uji Parsial

Coefficients $^{\mathrm{a}}$

\begin{tabular}{|ll|c|c|}
\hline \multicolumn{2}{|c|}{ Model } & T & Sig. \\
\hline 1 & (Constant) & 11.074 & .000 \\
& TI & .864 & .391 \\
& ROE & -2.110 & .040 \\
& ROA & 2.807 & .007 \\
& KL & 1.591 & .064 \\
\hline
\end{tabular}

a. Dependent Variable: ISR

Sumber: Diolah Peneliti, 2017

Hasil uji t untuk masing-masing variabel independen adalah sebagai berikut:

a. Tipe Industri (X1)

Diketahui hasil variabel Tipe Industri pada nilai signifikansi $\alpha=5 \%$ yaitu sebesar $0,391(0,391>0,05)$ serta $t$ hitung lebih kecil dari pada t tabel $(0,864<1,67303)$, menunjukkan bahwa Tipe Industri secara parsial berpengaruh tidak signifikan terhadap pengungkapan Islamic Social Reporting (ISR) yang berarti Hipotesis $1(\mathrm{H} 1)$ ditolak.

b. Return On Equity/ ROE (X2)

Diketahui hasil variabel ROE pada nilai signifikansi $\alpha=5 \%$ yaitu sebesar 0,040 $(0,040<0,05)$ serta t hitung lebih besar dari pada $t$ tabel $(2,110>1,67303)$, menunjukkan bahwa ROE secara parsial berpengaruh signifikan terhadap pengungkapan Islamic Social Reporting (ISR), yang berarti Hipotesis $2(\mathrm{H} 2)$ diterima.

c. Return On Asset/ ROA (X3)

Diketahui hasil variabel ROA pada nilai signifikansi $\alpha=5 \%$ yaitu sebesar 0,007 $(0,007<0,05)$ serta t hitung lebih besar dari pada $t$ tabel $(2,807>1,67303)$, menunjukkan bahwa Return On Asset/ ROA secara parsial berpengaruh signifikan terhadap pengungkapan Islamic Social Reporting (ISR), yang berarti Hipotesis $3(\mathrm{H} 3)$ diterima.

d. Kinerja Lingkungan (X4)

Diketahui hasil variabel Kinerja Lingkungan pada nilai signifikansi $\alpha=$ $5 \%$ yaitu sebesar $0,064(0,064>0,05)$ serta $t$ hitung lebih kecil dari pada $t$ tabel $(1,591<1,67303)$, menunjukkan bahwa Kinerja Lingkungan secara parsial berpengaruh tidak signifikan terhadap pengungkapan Islamic Social Reporting (ISR), yang berarti Hipotesis $4(\mathrm{H} 4)$ ditolak.

\subsection{Pembahasan Hasil Penelitian}

1. Pengaruh Tipe Industri terhadap Pengungkapan Islamic Social Reporting (ISR).

Diketahui dari hasil regresi linier bahwa Tipe Industri berpengaruh tidak signifikan terhadap Pengungkapan Islamic Social 
Reporting (ISR), dikarenakan tidak terdapat perbedaan yang kuat antara perusahaan manufaktur dan non manufaktur. Ditunjukkan dari analisis statistik deskriptif dengan hasil pengungkapan ISR, bahwa baik perusahaan manufaktur maupun non manufaktur, nilai rata-rata pengungkapkan item ISR nya adalah setara yaitu lebih dari $50 \%$ artinya semua jenis industri samasama mengungkapkan tanggung jawab syariahnya dengan seluas mungkin.

Perusahaan beranggapan bahwa pengungkapan ISR lebih pada kesadaran dan inisiatif masing-masing perusahaan itu sendiri, oleh sebab itu tipe industri tidak mempengaruhi besar kecilnya pengungkapan Islamic Social Reporting perusahaan. Hipotesis ini mendukung penelitian yang dilakukan oleh (Wulansari, 2016:11; Novrizal et al., 2016:187).

2. Pengaruh Return On Equity (ROE) terhadap Pengungkapan Islamic Social Reporting (ISR).

Berdasarkan hasil regresi, dapat diketahui bahwa variabel $R O E$ berpengaruh negatif signifikan terhadap Pengungkapan Islamic Social Reporting (ISR) sehingga semakin tinggi tingkat pengembalian kepada pemilik saham dari keuntungan yang dimiliki oleh perusahaan, maka pengungkapan tanggung jawab syariah perusahaan akan semakin kecil/ tidak diperluas, penyebabnya adalah perusahaan yang memiliki tingkat pengembalian yang tinggi belum tentu banyak melakukan aktivitas sosial karena perusahaan lebih berorientasi pada laba dan para pemilik saham semata.

Perusahaan dengan tingkat pengembalian yang tinggi menganggap tidak perlu melaporkan tentang hal-hal yang dapat mengganggu informasi bahwa perusahaan tersebut memberi keuntungan yang tinggi kepada para pemilik sahamnya. sedangkan pada tingkat pengembalian yang rendah, maka perusahaan berharap para pengguna laporan akan membaca hal lain seperti laporan kegiatan tanggung jawab sosial syariah perusahaan. Penelitian ini bertolak belakang dengan penelitian (Widiawati \& Raharja, 2012; Wulansari et al., 20116).

3. Pengaruh Return On Asset (ROA) terhadap Islamic Social Reporting (ISR).

Berdasarkan hasil regresi, dapat diketahui bahwa variabel $R O A$ berpengaruh signifikan terhadap Pengungkapan Islamic Social Reporting (ISR). Return On Asset (ROA) yang semakin tinggi menunjukkan bahwa perusahaan tersebut berada dalam kondisi yang baik.

Perusahaan dengan keadaan kinerja keuangan yang baik dapat mendorong perusahaan untuk meningkatkan kepeduliannya terhadap kegiatan tanggung jawab syariah perusahaan sebagai rasa syukur atas keuntungan yang didapatkan, Hipotesis ini mendukung penelitian yang dilakukan oleh (Wulandari, 2016:19; Taufik et al., 2015: 194).

4. Pengaruh Kinerja Lingkungan terhadap Pengungkapan Islamic Social Reporting (ISR).

Berdasarkan hasil regresi, menunjukkan bahwasannya variabel Kinerja Lingkungan berpengaruh tidak signifikan terhadap pengungkapan Islamic Social Reporting (ISR). Semakin tinggi angka yang diperoleh dalam pemeringkatan kinerja lingkungan yang diberikan oleh pemerintah berarti pengungkapan ISR akan semakin rendah.

Penyebabnya adalah pengungkapan ISR yang diungkapkan perusahaan yang masuk ke dalam penilaian PROPER tidak banyak diungkapkan dalam laporan tahunan perusahaan, karena perusahaan beranggapan sudah cukup memberikan informasi bahwa perusahaan tersebut mengikuti PROPER yang berarti bahwa masyarakat harusnya sudah memiliki pandangan yang baik bahwasannya perusahaan tersebut sudah peduli terhadap 
masalah lingkungan, maka dari itu, perusahaan tidak perlu memperjelas/ memperluas pengungkapan tanggung jawab sosial syariahnya/ Islamic Social Reporting dalam laporan tahunan terutama pada tema lingkungan dalam item ISR. Hipotesis ini mendukung penelitian yang dilakukan oleh Wulandari (2015:19) dan Kariza (2015: 11).

\section{Kesimpulan Dan Saran}

\subsection{Kesimpulan}

Tipe Industri berpengaruh tidak signifikan terhadap Pengungkapan Islamic Social Reporting. Return On Equity (ROE) berpengaruh negatif signifikan terhadap Pengungkapan Islamic Social Reporting (ISR). Return On Asset (ROA) berpengaruh signifikan terhadap Pengungkapan Islamic Social Reporting (ISR), serta Kinerja Lingkungan berpengaruh tidak signifikan terhadap Pengungkapan Islamic Social Reporting (ISR).

\subsection{Saran}

1. Bagi perusahaan agar lebih memperhatikan pelaporan tanggung jawab sosial syariahnya, seperti zakat, Qard Hassan, dan waqaf, karena ratarata perusahaan tidak menyebutkan point tersebut dalam laporan tahunannya.

2. Penelitian selanjutnya diharapkan dapat menambah item pengungkapan tanggung jawab sosial syariah perusahaan seperti kegiatan idul adha, Kegiatan ramadhan, santunan anak yatim, sunatan masal, dan kegiatan keagamaan yang sering diungkapkan pada laporan tahunan perusahaan namun tidak masuk dalam item ISR.

3. Meningkatkan variabel penelitian yaitu dengan menambah variabel independen lain selain variabel yang digunakan pada penelitian ini seperti variabel Laverage, Umur perusahaan, kepemilikan manajemen dan ukuran perusahaan.

\section{Daftar Pustaka}

Algifari. 2010. Analisis Regresi, Teori, Kasus dan Solusi (Edisi kedua). Yogyakarta: BPFE Yogyakarta.

Anggraini, Anita dan Mulyaning wulan. 2015. Faktor Financial-Non Financial dan Tingkat Pengungkapan Islamic Social reporting (ISR). Jurnal Akuntansi dan Keuangan Islam Vol. 2, No. 2 Hal. $161-184$.

Astuti, Tika. 2013. Pengaruh Profitabilitas, Likuiditas dan Laverage Terhadap Pengungkapan Islamic Social Reporting (Studi Empiris pada Perusahaan yang Terdaftar di JII Tahun 2010-2012). Jurnal Universitas Islam Negeri Syarif Hidayatullah Jakarta. Hal. 1-20.

Brealey, dkk. 2008. Dasar-Dasar Manajemen Keuangan Perusahaan Jilid 2 Edisi Kelima. Jakarta: Erlangga.

Ghozali, Imam. 2011. Ekonometrika. Semarang: Fakultas Ekonomi Universitas Diponegoro.

Hery. 2013. Akuntansi Jasa dan Dagang Praktis dengan Contoh Soal. Yogayakarta: GAVA MEDIA.

Kariza, Ayu. 2014. Faktor-Faktor Yang Mempengaruhi Pengungkapan Islamic Social Reporting Pada Perusahaan Yang Listing Di Jakarta Islamic Index tahun 2013. Jurnal Akuntansi. Hal. 1-13.

Kurniawati, Mahardika. 2016. Pengaruh Mekanisme Corporate Governance, Kinerja Keuangan dan Kinerja Lingkungan Terhadap 
Pengungkapan Islamic Social Reporting (ISR) (Studi Empiris pada Perusahaan-Perusahaan yang Termasuk dalam Daftar Efek Syariah (DES) dan Mengikuti Proper Tahun 2011-2015). Jurnal Akuntansi. Hal. 1-29

Merina, Citra Indah dan Verawaty. 2016. Analisis Komparasi Indeks Islamic Social Reporting Perusahaan Perbankan Syariah dan Perusahaan Go Publik Yang Listing Di Jakarta Islamic Index. Jurnal AKUISISI-Vol 12 No. 2 November 2016. Hal. 1-17.

Novrizal, MF dan Meutia Fitri. 2016. FaktorFaktor yang Mempengaruhi Pengungkapan Corporate Social Responbility (CSR) pada Perusahaan yang Terdaftar di Jakarta Islamic Index (JII) tahun 2012-2015 dengan Menggunakan Islamic Social Reporting (ISR) Index sebagai Tolok Ukur. 2016. Jurnal IImiah Mahasiswa Ekonomi Akuntansi (JIMEKA) Vol. 1, No. 2, Halaman 177-189.

Nurhayati, Sri dan Wasilah. 2013. Akuntansi syariah di Indonesia. Edisi 3. Jakarta: Salemba Empat

Nursiyono, Joko Ade. 2015. Kompas Teknik: Pengambilan sampel. Bogor: IN MEDIA

Othman, Rohana., Thani A.M., Ghani, E.K. 2010. "Determinants of Islamic Social Reporting Among Top Shariah-Approved Companies in Bursa Malaysia, Journal of International Studies - Issue 12, Hal. 4-20
Othman, Rohana dan Thani. 2011. Azlan. Islamic Social Reporting Of Listed Companies In Malaysia. International Business \& Economics research Journal,Volume 9, Number 4. Hal. 135-144.

Putri, Tria dan Yuyetta Etna. 2014. FaktorFaktor yang Mempengaruhi Islamic Social Reporting PerusahaanPerusahaan yang Terdaftar pada Indeks Saham Syariah Indonesia (ISSI) Tahun 2011-2012. 2014. Diponegoro Journal Of Accounting Volume 3, Nomor 2, Hal. 1-9.

Rama, Ali. 2014. Analisis determinan Pengungkapan Islamic Social Reporting: Studi Kasus Bank Umum Syarah di Indonesia". Equilibrum. Vol. 2, No. 1, Hal. 84-103.

Sartono, Agus. 2014. Manajemen Keuangan Teori dan aplikasi. Edisi 4. Yogyakarta: BPFE

Siregar, Syofian. 2013. Metode Penelitian Kuantitatif (dilengkapi dengan perbandingan perhitungan manual dan SPSS). Jakarta: PRENADAMEDIA GROUP.

Sugiyono. 2013. Metode Penlitian Bisnis. Bandung: Alfabeta

Sugiyono. 2014. Metode Penelitian Kuantitatif Kualitatif dan R\&D. Bandung: ALFABETA.

Sujarweni, Wiratna. 2016. Kupas Tuntas Penelitian Akuntansi dengan SPSS Edisi Lengkap. Yogyakarta: Pustaka Baru Press. 
Suliyanto. 2009. Metode Riset Bisnis. www.sahamok.com. Di akses Tanggal 1 Yogyakarta: ANDI OFFSET. April 2017.

Syamsudin, Lukman. 2011. "Manajemen Keuangan Perusahaan". Jakarta: RajaGrafindo Persada.

Taufik, Widianti, M., \& Rafiqoh. (2015). Pengaruh Islamic Governance Scoe, Leverage dan Profitabilitas Terhadap Islamic Social Reporting Index Pada Bank Umum Syariah di Indonesia. Jurnal Manajemen dan Bisnis Sriwijaya, 177-198.

Triyuwono, Iwan. 2015. Akuntansi Syariah: Perspektif, Metodologi, dan Teori. Edisi kedua. Jakarta: Raja Grafindo Persada.

Widiawati, Septidan Surya Raharja. 2012. Analisis Faktor-Faktor yang Mempengaruhi Islamic Social Reporting Perusahaan Perusahaan Yang Terdapat Pada Daftar Efek Syariah Tahun 20092011. Diponegoro Journal Of Accounting. Volume 1, Nomor 2, Halaman 1-15.

Wulandari, Fitri. 2016. Pengaruh Profitabilitas, Ukuran Perusahaan, Kinerja Lingkungan, dan Leverage Terhadap Pengungkapan Islamic Social Reporting (Studi Empiris pada Perusahaan yang Terdaftar di Daftar Efek Syariah Tahun 2014). Hal. 1-23.

Wulansari, WD, dkk. 2016. Faktor-Faktor yang Mempengaruhi Islamic Social Reporting Perusahaan yang Terdaftar Di Efek Syariah Tahun 2014-2015. Hal. 1-15. www.menlh.go.id. Di akses Tanggal 9 April 2017.

www.idx.co.id. Di akses Tanggal 9 April 2017. 